\author{
Marquette University \\ e-Publications@Marquette
}

College of Education Faculty Research and

Publications

Education, College of

$12-2007$

\title{
Becoming Psychotherapists: Experiences of Novice Trainees in a Beginning Graduate Class
}

\author{
Clara E. Hill \\ University of Maryland \\ Catherine Sullivan \\ University of Maryland \\ Sarah Knox \\ Marquette University, sarah.knox@marquette.edu \\ Lewis Z. Schlosser \\ Seton Hall University
}

Follow this and additional works at: https://epublications.marquette.edu/edu_fac

Part of the Clinical Psychology Commons, and the Education Commons

\section{Recommended Citation}

Hill, Clara E.; Sullivan, Catherine; Knox, Sarah; and Schlosser, Lewis Z., "Becoming Psychotherapists:

Experiences of Novice Trainees in a Beginning Graduate Class" (2007). College of Education Faculty

Research and Publications. 26.

https://epublications.marquette.edu/edu_fac/26 


\title{
Becoming Psychotherapists: Experiences of Novice Trainees in a Beginning Graduate Class
}

\author{
Clara E. Hill \\ Department of Psychology, University of Maryland \\ College Park, MD \\ Catherine Sullivan \\ Department of Psychology, University of Maryland \\ College Park, MD \\ Sarah Knox \\ Department of Counseling and Educational Psychology, \\ Marquette University \\ Milwaukee, WI \\ Lewis Z. Schlosser \\ Department of Professional Psychology and Family Therapy, \\ Seton Hall University
}

South Orange, NJ

\begin{abstract}
The authors investigated the experiences related to becoming psychotherapists for 5 counseling psychology doctoral trainees in their first prepracticum course. Qualitative analyses of weekly journals indicated that trainees discussed challenges related to becoming psychotherapists (e.g., being self-critical, having troubling reactions to clients, learning to use helping skills), gains made during the semester related to becoming psychotherapists (e.g., using helping skills more effectively, becoming less self-critical, being

Psychotherapy: Theory, Research, Practice, Training, Vol. 44, No. 4 (December 2007): pg. 434-449. DOI. This article is (C) American Psychological Association and permission has been granted for this version to appear in e-

Publications@Marquette. American Psychological Association does not grant permission for this article to be further copied/distributed or hosted elsewhere without the express permission from American Psychological Association.
\end{abstract}


NOT THE PUBLISHED VERSION; this is the author's final, peer-reviewed manuscript. The published version may be accessed by following the link in the citation at the bottom of the page.

able to connect with clients), as well as experiences in supervision and activities that helped them cope with their anxieties. Results are discussed in 5 broad areas: feelings about self in role of psychotherapist, awareness of reactions to clients, learning and using helping skills, reactions to supervision, and experiences that fostered growth. Implications for training and research are provided.

An examination of the experiences of psychotherapy trainees illuminates not only what they absorb from training but also where they struggle and where they triumph. Such understanding is particularly important with novice psychotherapists, because their initial training experiences likely provide the foundation for subsequent learning. Hence, the purpose of this study was to investigate the experiences of psychotherapy trainees in their first semester of graduate training.

In their book on the development of therapists and counselors, Skovholt and Ronnestad (1992) reviewed several leading theories of therapist and counselor development. Fleming (1953), for example, described the beginning stage of psychotherapist development as involving mostly the trainee imitating the supervisor, with the supervisor focusing on teaching, suggestion, and demonstration. Hogan (1964) suggested that trainees at this level were insecure, "neurosis bound," and dependent, with little insight into their motivation for being psychotherapists; furthermore, he contended that novice trainees are often highly motivated but frequently rely on one method and learn through imitation. According to Hill, Charles, and Reed (1981), beginning psychotherapists are sympathetically involved with clients and thus most often use interventions that provide positive support. Loganbill, Hardy, and Delworth (1982) theorized that novice psychotherapists are unaware of their deficiencies in professional functioning and hold a constricted view of the world; such trainees either have a low self-concept and are dependent on the supervisor or think they are functioning well and believe that they have no need of supervision. Somewhat in contrast to the prior described theories, Grater (1985) suggested that novice trainees readily adopt basic skills and the psychotherapist role to manage their acute anxiety. Finally, Hess (1987) believed that novice trainees are involved primarily with role induction, demystification of psychotherapy, skill definition, and setting of boundaries.

Psychotherapy: Theory, Research, Practice, Training, Vol. 44, No. 4 (December 2007): pg. 434-449. DOI. This article is (C) American Psychological Association and permission has been granted for this version to appear in e-

Publications@Marquette. American Psychological Association does not grant permission for this article to be further copied/distributed or hosted elsewhere without the express permission from American Psychological Association. 
Skovholt and Ronnestad (1992) then integrated these theories, in combination with data derived from interviews with master psychotherapists, to postulate eight stages of therapist development, the first two of which focus on novice trainees. First, in the conventional stage, untrained psychotherapists rely on natural, simple, and unexamined methods for helping others, often giving advice and using direct problem-solving techniques. In the next stage (i.e., professional training), trainees are enthusiastic yet insecure about their performance; because they feel they can no longer use known skills, they try as quickly as possible to fill the void and learn techniques and are thus very influenced by professors and supervisors.

Complementing these developmental theories is empirical research on the actual experiences of novice trainees. In an investigation of seven trainees, their clients, and their supervisors in graduate prepracticum training, Williams, Judge, Hill, and Hoffman (1997) found that trainees were concerned about their therapeutic skills, performance, ability to connect with clients, anxiety, selfefficacy, role as psychotherapist, similarities to and differences from clients, and problematic reactions to clients. To cope with these potentially problematic reactions, trainees developed a range of management strategies (e.g., focusing on the client, positive self-talk). Because this study relied on postsession, written questionnaire data, however, it was not as rich and comprehensive as would be possible with more open-ended and ongoing data collection methods. Furthermore, the Williams et al. study did not focus on trainees' internal reactions to training, which seem important when studying experiences of beginning trainees.

Other researchers in this area have focused on critical incidents (i.e., significant learning moments or turning points) in the development of novice psychotherapists (Furr \& Carroll, 2003; Howard, Inman, \& Altman, 2006; Lee, Eppler, Kendal, \& Latty, 2001) and have begun to identify influences on novice psychotherapist development, particularly in terms of distinct dramatic events that may occur. In many ways similar to the findings of Williams et al., these studies found evidence that such critical incidents involved trainees grappling with self-awareness and self-efficacy as psychotherapists, feelings of similarity and difference in relation to clients, self-criticalness of performance in sessions, concerns about

Psychotherapy: Theory, Research, Practice, Training, Vol. 44, No. 4 (December 2007): pg. 434-449. DOI. This article is (C) American Psychological Association and permission has been granted for this version to appear in e- 
taking on the psychotherapist role, difficulties related to clients not meeting expectations, the helpful nature of supervision, and selfreflection. One concern with this line of research, however, is that it focuses solely on critical incidents and thus may not reflect the range of experiences involved in becoming a psychotherapist. For example, when describing critical events, trainees might not include such things as difficulties with the logistics of managing sessions or their internal reactions to clients. When trainees are asked, in an open-ended way, to describe all of their experiences, they may include content that would not appear when they are instructed to focus only on critical incidents.

Other researchers have focused on the experiences of novice trainees in supervision, a crucial component of their learning to become psychotherapists. Heppner and Roehlke (1984), for example, found that most of the critical incidents in supervision of beginning practicum students involved issues related to support and selfawareness; trainees were satisfied with supervision when they received support and skills training. In another study involving a critical incidents methodology, trainees cited supervisory support, treatment planning, advice, and direction as the most important supervisory interventions (Rabinowitz, Heppner, \& Roehlke, 1986). These two studies provide some initial information about the experiences of novice trainees in supervision, but they need to be updated and replicated using more in-depth qualitative methods to examine the range of reactions and discover more about how trainees use supervision to become psychotherapists.

In sum, although some research has been conducted on the development of novice trainees, more work is needed to examine the range of training and supervision experiences rather than just the critical incidents. Furthermore, more attention is warranted regarding how trainees cope with their anxieties in their initial training experiences. Our goal in the present study, then, was to begin to fill such gaps in the existing literature by examining the lived experiences of novice psychotherapists during their first semester of graduate training. By investigating the experiences of novice trainees, we hoped to gather information that would help us improve training. For instance, most training programs currently focus on teaching helping skills or provide specific training in manualized treatments; however, 
we do not know, from the trainee perspective, whether these foci fit their developmental needs.

Because we wanted to learn about trainees' inner experiences, specifically regarding their feelings and concerns about becoming psychotherapists, we analyzed the text of weekly journals written across the course of a semester. Journaling (Howatt, 1999; Naviaux, 1980; Progoff, 1977; Tsang, 2003; Wagoner \& Wijekumar, 2004) is often used in counseling classes to help students process their experiences and become more self-reflective; indeed, journaling has been shown to benefit counselor development (Burnett \& Meacham, 2002). Journaling has also been used in previous studies on the experiences of novice psychotherapists (Howard et al., 2006; Lee et al., 2001) and thus seems an appropriate method for this area. In addition to helping the trainees, we hoped that the data from their journals would provide us with a rich sense of the trainees' experiences, including important thoughts and feelings that might not surface using quantitative measures, class discussions, or supervision sessions.

Toward that end, we chose a qualitative approach to capture the richness and depth of trainee experiences as expressed in journals across the course of a semester. Specifically, we used consensual qualitative research (CQR; Hill, Thompson, \& Williams, 1997; Hill et al., 2005), because it allowed us to explore themes within and across trainees over time.

One feature of the qualitative method used for collecting these data is that the professor and research assistant provided questions and feedback to the students during the semester and served as the primary research team for analyzing the data. Although potentially controversial, there is precedent for researchers being involved in both data collection and analysis, based on the rationale that doing so allows them to be immersed in the data and thus develop a deep understanding of the phenomenon (Kidd \& Kral, 2005; Mishler, 1990; Moustakas, 1990; Rhodes, Hill, Thompson, \& Elliott, 1994). To address potential concerns about bias in this procedure, we used two external auditors to ensure that conclusions were solidly based on the data (note that many qualitative methods do not use auditors or rely on a sole auditor; see review in Hill et al., 2005).

Psychotherapy: Theory, Research, Practice, Training, Vol. 44, No. 4 (December 2007): pg. 434-449. DOI. This article is (C) American Psychological Association and permission has been granted for this version to appear in e- 
NOT THE PUBLISHED VERSION; this is the author's final, peer-reviewed manuscript. The published version may be accessed by following the link in the citation at the bottom of the page.

Finally, we conducted this research within a single graduate class with five students; thus we essentially conducted a small sample exploratory study of trainees' experiences in one training model with one professor. Because training experiences are undoubtedly influenced by the instructor, the individual trainees, and the curriculum, it seems reasonable to begin such exploratory studies by investigating trainees within an individual class.

\section{Method}

\section{The Class}

The 15-week, semester-long, required course was structured around the Hill (2004a) helping skills text. Thus, the course focused first on training students (note that the terms student and trainee are used interchangeably in this article) in the exploration stage (with the related skills of open question, restatement, reflection of feelings, and silence), then on the insight stage (with the related skills of challenge, interpretation, self-disclosure of insight, and immediacy), and finally on the action stage (with the related skills of information and direct guidance). The skills training was experiential, with students practicing the skills with one another. Four 3-hr sessions focused on skills training for the exploration stage early in the course, two 3-hr sessions focused on the insight stage at midsemester, and two 3-hr sessions addressed the action stage at the end of the course. After 1 month of training in the exploration skills, trainees began seeing volunteer clients recruited from upper level undergraduate classes who received course credit for participating, with each trainee seeing three to five clients for a total of 10 to 12 50-min sessions. In addition, students read and discussed several books focused on theories of psychotherapy (Atkinson, 2004; Elliott, Watson, Goldman, \& Greenberg, 2004; Hill, 2004b; Linehan, 1993; McWilliams, 2004; Miller \& Rollnick, 2002; Safran \& Muran, 2003) to gain a deeper understanding of the theories underlying the skills. Overall, students spent $6 \mathrm{hr}$ per week in class (3 hr discussing theories or practicing helping skills, $1 \mathrm{hr}$ seeing volunteer clients while being observed in vivo by supervisors, $1 \mathrm{hr}$ observing classmates in sessions, and $1 \mathrm{hr}$ in individual supervision with an advanced doctoral student in a supervision practicum). In addition to the journal assignment (see

Psychotherapy: Theory, Research, Practice, Training, Vol. 44, No. 4 (December 2007): pg. 434-449. DOI. This article is (C) American Psychological Association and permission has been granted for this version to appear in e- 
later discussion), students had other assignments for the class (a selfexamination paper about their theory of personality and psychotherapy, a transcript of a session, and a paper evaluating the effectiveness of their interventions within the transcribed session and of the outcome of sessions compared to published data).

The professor, who was also the first author of this article, sought to foster a seminar atmosphere in which everyone's opinion was valued equally. She believed that the best way to learn about theories is to read and discuss them in class and the best way to learn the skills is to practice them. The professor strove to build a sense of trust so that students could safely reveal their ideas about theories and disclose personal issues for experiential practice. In addition, students were told that deep self-examination is important, as the professor believed that the person of the psychotherapist is a major instrument for helping clients change. The professor introduced the concept of hot buttons (i.e., strong reactions to clients based on personal issues) in class and encouraged trainees to examine their own hot buttons in class, in their journals, and in supervision. In addition, trainees were asked to look for ways that they might be influenced by cultural similarities and differences with their clients. All students indicated (during follow-up interviews) that they had felt safe in the class and in writing in their journals.

\section{Participants}

Trainees. Trainees were five (three women, two men; four European Americans, one multiracial) students in their first semester of a counseling psychology doctoral program. Four of the students were 22 to 25 years old, and one student was 46 years old. Four had undergraduate majors in psychology (three had double majors-one in music, one in Spanish, and one in philosophy); one had an undergraduate major in English and had returned to school to take courses in psychology. One student entered the program with a master's degree in educational psychology; the other four entered postbaccalaureate. Graduate Record Examination (GRE) verbal scores ranged from 570 to $760(M=644.00, S D=72.32)$; GRE quantitative scores ranged from 670 to $760(M=714.00, S D=33.62)$; overall undergraduate grade point averages ranged from 3.73 to 3.85 ( $M=$ 
NOT THE PUBLISHED VERSION; this is the author's final, peer-reviewed manuscript. The published version may be accessed by following the link in the citation at the bottom of the page.

$3.80, S D=0.05)$, indicating that this was a very bright group of students. Four students had no prior clinical experience, and one student had minimal clinical experience (she had co-led one eating disorders group). None had participated in any prior helping skills training.

Primary team and auditors. The professor (a 56-year-old European American woman) and graduate research assistant (GRA; a 32-year-old European American woman in her second year as a doctoral student, who had taken the course the previous year) read the journals, responded weekly with probing questions and comments, and served as the primary research team for analyzing the data. A 44year-old European American female associate professor and a 33year-old American Ashkenazi Jewish male assistant professor, both with doctorates in counseling psychology, served as auditors. The auditors had graduated from the program where the study was conducted, but they were now at other universities and did not know the trainees involved in the present study.

Because the primary team in this study consisted of a professor and a GRA, there was an inherent power imbalance. They worked hard to make sure that both "voices" were heard equally (e.g., one person was not considered to be "right" any more than the other, they alternated who spoke first about ideas, and they discussed disagreements openly). The team recognized the value of each other's unique perspective and enjoyed working together. In addition, the auditors and the professor had collaborated on a number of other qualitative projects, respected each other, and worked well together.

As is customary with qualitative research, and as is particularly important because the professor and GRA were involved in all phases of the study, we present the biases of the four research team members here. All believed in the benefit of helping skills training for novice psychotherapists, the importance of identifying and managing hot buttons, and the need for self-reflection and honesty. All were committed to trainee self-reflection and believed that developing awareness of one's biases and personal issues is critical in becoming a psychotherapist. None were committed to students becoming a certain type of psychotherapist (e.g., psychodynamic); rather, the group believed that students should think critically about all theories and

Psychotherapy: Theory, Research, Practice, Training, Vol. 44, No. 4 (December 2007): pg. 434-449. DOI. This article is (C) American Psychological Association and permission has been granted for this version to appear in e-

Publications@Marquette. American Psychological Association does not grant permission for this article to be further copied/distributed or hosted elsewhere without the express permission from American Psychological Association. 
NOT THE PUBLISHED VERSION; this is the author's final, peer-reviewed manuscript. The published version may be accessed by following the link in the citation at the bottom of the page.

choose parts that fit for them. These biases were discussed prior to the study and attempts were made to bracket (i.e., set aside) them and continually return to the data to ensure that there was evidence for all conclusions.

\section{Journals}

Trainees wrote two to four typed pages in weekly journal entries. They were told to write about any of the following topics: helping skills, competence as a psychotherapist, countertransference, anxiety, self-efficacy, reactions to supervision, learning about psychotherapy (e.g., theory, theoretical orientation, case management), cultural issues (e.g., gender, race/ethnicity, age, religion, socioeconomic status, sexual orientation), ethics, the process of becoming a psychotherapist (i.e., socialization), reactions to class, or anything else that seemed relevant to their growth and development as psychotherapists or to the class. In a final, longer journal entry, trainees reflected back on their changes during the semester.

\section{Procedures}

Recruiting participants. During the first class, trainees were told about the study approved by the institutional review board. They were informed that the journal was required as part of the class but that they did not have to disclose any information in the journal that they did not want to, that grading of the journal was pass/fail, that use of their data for the study was completely voluntary, and that they could withdraw permission at any time without jeopardy. Trainees signed a consent form indicating their awareness of what was involved in the research. Trainees were also given opportunities to discuss the study throughout the semester. Finally, trainees were given another opportunity to give informed consent at the end of the semester when they were aware of what they had written in their journals. Although all consented for their data to be used, the researchers did not know who had agreed to participate until after the semester had ended.

Journals. Students submitted their weekly journals via email. Both the professor and the GRA read each entry and sent feedback

Psychotherapy: Theory, Research, Practice, Training, Vol. 44, No. 4 (December 2007): pg. 434-449. DOI. This article is (C) American Psychological Association and permission has been granted for this version to appear in e- 
(typically offering support, asking students to expand on topics, challenging discrepancies, or asking students to comment about something related to the class such as one of the readings) to each student at least 3 days before the due date of the next entry. Students typically added both new commentary and responded to some of the comments or questions in subsequent entries.

Data analysis. Data analysis, which began after the semester was completed, followed CQR guidelines (Hill et al., 1997, 2005). The two primary team members reviewed the journals and developed domains or topic areas (e.g., challenges in becoming therapists, gains over the semester, experiences that fostered growth). The primary team then read a coherent section (usually a paragraph or two) of a journal entry and assigned it by consensus to one or more relevant domains. They then formulated core ideas (i.e., an abstract or summary of the data in clear and concise statements) for the data within each domain for each trainee.

The consensus version for each trainee (journal excerpts and associated core ideas within each domain for each week) was sent to the two auditors, who determined whether the journal material was placed in the appropriate domain and whether the core ideas fit the data. Auditors typically made numerous suggestions, ranging from wording to ideas for the domain structure. The primary team examined the audits, returning to the raw data as necessary, and decided on changes by consensus.

The primary team then created a cross-analysis by developing categories that reflected the content of the core ideas for each domain across trainees. They placed each core idea into one or more relevant categories. The auditors examined the cross-analyses and made many suggestions for modifying categories, challenged the placement of core ideas into categories, and commented on the overall category structure. The primary team considered the auditors' comments and made modifications by consensus, going back to the raw data to gather evidence as necessary. This process was repeated several times until all agreed that the cross-analysis was a good representation of the data.

Psychotherapy: Theory, Research, Practice, Training, Vol. 44, No. 4 (December 2007): pg. 434-449. DOI. This article is (C) American Psychological Association and permission has been granted for this version to appear in e-

Publications@Marquette. American Psychological Association does not grant permission for this article to be further copied/distributed or hosted elsewhere without the express permission from American Psychological Association. 
NOT THE PUBLISHED VERSION; this is the author's final, peer-reviewed manuscript. The published version may be accessed by following the link in the citation at the bottom of the page.

Follow-up interviews. Approximately 8 months after the end of the semester, students read the consensus versions of their data and then met individually with the professor and GRA to discuss their reactions. All students indicated that the core ideas for their data were accurate.

Verification with participants. Approximately 1 year after data collection, the results were presented at a conference, with trainees participating and providing reactions. In addition, trainees read and commented on a draft of the manuscript and gave approval for the data to be published as presented. Their thoughts were incorporated into the final draft of the manuscript.

\section{Results}

The following domains related to becoming psychotherapists emerged through the data analysis: (a) challenges related to becoming psychotherapists, (b) gains related to becoming psychotherapists, (c) supervision, and (d) experiences other than supervision that fostered awareness. Other topics discussed in journals that were not directly related to becoming psychotherapists (e.g., emerging theory of personality and psychotherapy, personal issues not directly related to being a psychotherapist, reactions to journaling, and reactions to student cohort) were not included in this article. See Table 1 for a listing of the domains, categories, and subcategories. In both the text and table, domains, categories, and subcategories are presented in descending order of the frequency of occurrence across trainees. In the text, we specifically mention when categories occurred more often at one point of the semester than another.

Following the precedent set in Williams et al. (1997), we discuss results only for those domains, categories, and subcategories that emerged as at least typical across trainees (fit for at least three of the five trainees) and were at least variant within each trainee (arose in at least two different journal entries across the semester). These results thus represent data that were discussed in more than one journal entry for most of the trainees.

Psychotherapy: Theory, Research, Practice, Training, Vol. 44, No. 4 (December 2007): pg. 434-449. DOI. This article is (C American Psychological Association and permission has been granted for this version to appear in ePublications@Marquette. American Psychological Association does not grant permission for this article to be further copied/distributed or hosted elsewhere without the express permission from American Psychological Association. 


\section{Challenges Related to Becoming Psychotherapists}

Trainees wrote most about challenges they encountered in the process of becoming psychotherapists. They discussed being selfcritical, their reactions to clients, the process of learning and using the helping skills, and session management.

Self-criticism. Trainees criticized specific aspects of their performance as therapists (other than using helping skills). All trainees felt quite anxious about beginning to see clients: They worried about knowing what to do in sessions (e.g., "My main feeling ... was that [the client] had so many different things going on with her 'coming out' that I didn't even know where to go first.") and felt pressured to do the "right" thing to be a good psychotherapist (e.g., "I still find myself worried about saying the right thing. My mind thinks very quickly and it is sometimes hard for me to quiet my mind and articulate the thoughts into coherent statements.").

In addition, trainees reported a range of other variant selfcriticisms: problems with self-awareness in sessions (e.g., being fully present with the client, being aware of their own feelings and reactions, not being distracted by hindering self-awareness and selfconsciousness), worry about their therapeutic abilities (i.e., feeling incompetent and impatient with themselves), discomfort with the therapist role such as feeling more like a friend than a therapist, and lack of clinical skills (not being able to get the client to go beyond storytelling and into more substantive disclosure, pushing too hard, being too sympathetic, allowing the client to complain the whole session, getting into negative thinking, using overly complex and lengthy interventions, making poor transitions between topics, and not having good termination skills).

Reactions to clients. Trainees wrote about three kinds of reactions to clients. First, they described feelings of under- and overidentification with their clients. In terms of underidentification, they focused on differences and expressed concerns that clients would not be able to relate to them because they had not had similar experiences (i.e., of coming out as being homosexual or being in a religious order). Here, trainees noted differences related to cultural 
identity (race/ethnicity, gender, sexual orientation, and age), with reactions ranging in intensity from simply noting that there were differences to being quite concerned about how to handle the differences. One trainee wrote, "In terms of my client today, I had a lesbian student who was in the process of coming out ... I wasn't sure if I felt up to the challenge. More of what I thought was that she would not react very well to me if she didn't feel I could understand what she was going through, as I obviously can't." They also wrote about overidentification or feeling too similar to clients to be able to step back and be objective in helping them. As an example, clients' concerns reminded some trainees of problems they had with their own siblings (e.g., "This .... Her issues pulled so hard on my own, that I had to tell myself to keep it together, to be there for her.").

Second, trainees expressed some dismay when clients did not conform to their expectations of how clients should ideally behave in sessions. Trainees were sometimes frustrated, for instance, when they perceived that clients were reluctant to become deeply involved. They were also sometimes anxious when their volunteer clients (upper level undergraduate psychology students) were psychologically sophisticated and did not seem to want or need the help trainees could offer (e.g., "My client was very psychologically minded, and throughout the session she talked about "transference," "unconditional positive regard," "ADHD," "OCD," etc. I was also aware that she has taken the helping skills course, and is currently in the Introduction to Counseling class. I think that when she opened the session this way, it made me initially more nervous ... because I was concerned that she had clear expectations for how a counseling session should go."). In addition, trainees had difficulty when clients seemed very disturbed or fragile and needed more than the trainee could offer.

Third, trainees felt pulled to step out of the psychotherapist role and do something that they thought they should not do, such as fix the client, give gratuitous advice, self-disclose inappropriately, soothe the client, or cry with or for clients. One trainee wrote, "I think that the overwhelming majority of the people in my life for whom I have empathy are family and friends. Perhaps because I am so used to feeling empathic and 'giving advice' with those people, I feel pulled to act similarly with client at times." 
NOT THE PUBLISHED VERSION; this is the author's final, peer-reviewed manuscript. The published version may be accessed by following the link in the citation at the bottom of the page.

Learning and using the helping skills. The trainees usually wrote about the skills that they were learning at the time that they were writing in their journals (e.g., exploration skills initially, insight skills in midsemester). In terms of exploration skills (reflection of feelings, restatement, open question, silence, and nonverbal and attending behaviors), they expressed uncertainty about how to formulate these skills to help clients explore and talk at a deep level about their problems (e.g., "I always felt a sense of challenge when I would try to really pinpoint what exactly the client was feeling and think of a good way to reflect that."). They were particularly concerned about formulating open questions that were not repetitive or stilted (e.g., "It really was challenging to think of questions that would be open enough to keep the client exploring, and that were not repetitive.").

Trainees were also apprehensive about using insight skills (challenge, immediacy, self-disclosure, and open questions for insight) accurately and appropriately. They found insight skills difficult to master because they were quite different from communication skills ordinarily used with friends (e.g., "I was kind of nervous of having a point come up during session where a client [was] looking to me for some kind of insight and I had none to give."). In addition, they worried specifically about making good interpretations and not wanting to intrude on clients (e.g., "Part of me was nervous at first. I didn't want to give a "bad" interpretation or wrong insight.").

Trainees seldom mentioned difficulties with learning or using action skills or with knowing how to integrate skills within or across stages (i.e., when to use the various skills). Of course, we would note that action skills were learned toward the end of the semester and not much time was spent in the class on integrating the skills.

Session management. Trainees mentioned difficulties managing the logistics of sessions. They felt disappointed, guilty, frustrated, and worried but also sometimes temporarily relieved when they were unable to recruit clients, when clients did not show up for sessions, when clients canceled after having agreed to attend sessions, or when clients terminated. According to one trainee, "I was feeling really disappointed coming into last Wednesday because my client from the week before had cancelled. And while I know that it wasn't

Psychotherapy: Theory, Research, Practice, Training, Vol. 44, No. 4 (December 2007): pg. 434-449. DOI. This article is C American Psychological Association and permission has been granted for this version to appear in ePublications@Marquette. American Psychological Association does not grant permission for this article to be further copied/distributed or hosted elsewhere without the express permission from American Psychological Association. 
NOT THE PUBLISHED VERSION; this is the author's final, peer-reviewed manuscript. The published version may be accessed by following the link in the citation at the bottom of the page.

necessarily because of what I had done in the session, there is definitely a part of me that thought it was."

\section{Gains Related to Becoming Psychotherapists}

Trainees wrote about major strides during the semester in their journey toward becoming psychotherapists. Somewhat in parallel with the challenges described previously, they reported gains in using the helping skills, being less self-critical, and being able to connect with clients.

Using the helping skills. After receiving helping skills training in class and practicing the skills in sessions with volunteer clients, trainees described progress in using the skills. In terms of exploration skills, they particularly mentioned feeling good about their ability to use reflection of feelings (e.g., "I have been asking my clients what they found helpful in sessions, and I think most of them have made some comment about how it was helpful that I reflected some of their feelings, because a lot of the times they had not really focused on them, and were maybe not really aware of how strong they were."), restatement (e.g., "Being able to summarize what I heard in terms of the client's thoughts and feelings made it easier to tune in to the point that the client was trying to make, and it seemed to, in most cases, help the client to focus on their problems and to continue to talk."), open question (e.g., "I feel like I was able to get her [client] to explore some of her emotions through open questions."), and silence (e.g., "I also have become a lot more comfortable with using silence to give the client some time to think and respond before jumping right in and saying something just to keep things moving."). They also described gains with exploration skills in general (e.g., "My exploration skills have improved a great deal, and these skills are definitely the ones that I am most comfortable with at this point.").

In addition, trainees described gains with insight skills. They felt better about using challenge (e.g., "I pointed out this contradiction using a challenge, and I think it really facilitated him [client] exploring this more deeply."), immediacy (e.g., "For some reason, it wasn't scary or anxiety provoking when [client] and I talked about our relationship and her views on our sessions. I felt like our bond was strengthened, and in my opinion, it helped her to explore some issues

Psychotherapy: Theory, Research, Practice, Training, Vol. 44, No. 4 (December 2007): pg. 434-449. DOI. This article is (C) American Psychological Association and permission has been granted for this version to appear in e- 
deeper than she did before we talked about our relationship."), and insight skills generally (e.g., "At the end of the session when we were finally talking about this being an issue of control, she [client] really bought into that and it almost made the whole session seem a lot better. This was the first time where I saw a client kind of find the centerpiece to their issues in the session, kind of like an epiphany."). Here, too, they rarely mentioned gains related to using action skills.

Feeling better about self as therapist. As the semester progressed, trainees reported feeling better about being in the therapist role. Specifically, they felt less anxious about seeing clients (e.g., they began to feel pride and relief for having survived the initial sessions, and then gradually came to feel more comfortable sitting in the room with clients). Thus, one trainee wrote, "I think that the anxiety I did have was due to some idea of what a psychologist is and my being unable to live up to this idea. Am I smart enough? Am I a good enough listener? These kinds of questions were constantly on my mind when I started this process and have pretty much disappeared at this moment. I can honestly say that now when I see a client I don't have any anxiety around my effectiveness or ability as a therapist."

They also reported increased self-efficacy and confidence in their abilities as therapists (e.g., "My self-efficacy for being a therapist has been going up as my anxiety has been decreasing throughout the semester. And I think that the increase in my self-efficacy has been for many of the same reasons that my anxiety has been decreasing, the biggest of these being that I have come to see that there is no one 'right' way that a session should look."). Finally, they felt more comfortable taking on the role of psychotherapist in that they felt more like real psychotherapists and less like imposters (e.g., "With each new client, I become increasingly more comfortable in the role of therapist, which makes it easier for me to focus on my client and to think more clearly about the interventions I am doing.").

Able to connect with clients. Trainees noted that they were better able to connect with clients. They felt more empathic and relieved when clients were open, receptive, and talkative. According to one trainee, "Her crying came mostly out of loneliness and I think there must have been a part of me that was really touched ... I do

Psychotherapy: Theory, Research, Practice, Training, Vol. 44, No. 4 (December 2007): pg. 434-449. DOI. This article is (C) American Psychological Association and permission has been granted for this version to appear in e- 
NOT THE PUBLISHED VERSION; this is the author's final, peer-reviewed manuscript. The published version may be accessed by following the link in the citation at the bottom of the page.

think part of my reaction was because her emotions elicited something in me. I think it was also out of extreme connection."

\section{Supervision}

Trainees mentioned that they used supervision to help them cope with anxieties and difficulties that arose during the semester. One trainee wrote, "Exploring my own reactions and feelings to [client] with my supervisor confirmed and validated what I was thinking and feeling during the session."

Trainees also noted specific supervisor behaviors that were helpful. They found it helpful when supervisors provided instruction or took a fairly active, directive, and didactic role in the supervision by teaching, guiding, advising, using role plays, or clarifying expectations about supervision. According to one trainee, "I was having a hard time allowing silence, and my supervisor encouraged me to give it a try. She also suggested that I not work quite so hard to find the next big connection and offer it up to the client." They also liked support, such as positive feedback, reassurance, empathy, affirmation, as empowerment to develop their own answers. In the words of one of them, "My supervisor was tremendously supportive which encouraged me in the process. She told me I did 'great' which confirmed my feeling confident about the session." In addition, trainees found it helpful when supervisors facilitated exploration of concerns related to becoming therapists or of related personal issues that influenced their work with clients (e.g., "She has really helped me explore some deeper issues about my own 'hot buttons' which I have mentioned in these journals [i.e., my 'problem' with men]."). Finally, trainees found it helpful when supervisors challenged them or provided them with specific feedback about what was not going well in sessions (e.g., "A really big part of why I may have had trouble exploring distress more deeply is my inexperience in the role as therapist. I feel like I don't want to leave a client feeling worse when they leave than when they come in. When I told this to my supervisor, he said, 'It sounds like you don't want to do therapy with her.' This is something that really struck me, and I have been thinking a lot about it since.").

In addition to these specific ways in which supervisors were viewed as helpful, all trainees described global positive feelings about

Psychotherapy: Theory, Research, Practice, Training, Vol. 44, No. 4 (December 2007): pg. 434-449. DOI. This article is (C) American Psychological Association and permission has been granted for this version to appear in $\mathrm{e}$ -

Publications@Marquette. American Psychological Association does not grant permission for this article to be further copied/distributed or hosted elsewhere without the express permission from American Psychological Association. 
their supervisors: They liked their supervisors and had good working alliances with them. For example, "I really like my supervisor. I find her incredibly easy to relate to and talk to at a personal level. She comes across as kind, caring and very supportive-an environment that makes me feel safe making mistakes and trying new things ... She is very attentive to my needs and learning styles and personal issues going into this process (of learning therapy)."

However, some trainees also had some neutral or negative reactions to their supervisors. On the neutral end of the continuum, trainees sometimes mentioned mild disagreements with their supervisors, typically related to differences of opinion or style. At the more negative end of the continuum, two trainees complained at the beginning of the semester about a lack of clear expectations about supervision and about difficulties in the supervisory relationships. One trainee wrote, "I have never had a feeling of our relationship being equal or even what it was supposed to be. Should I treat him more as a teacher or a friend? Should I try to get to know him better personally as a peer or not because he is my supervisor? ... While I would like to be able to know my supervisor better and joke around with him, I would much rather give that piece up for a definite explanation of what his role is for me." Sensing their dissatisfaction, the supervisor clarified expectations and used immediacy to work on the supervisory relationships, so that these two trainees felt mostly positive about their supervision experiences by the end of the semester. It is worth noting that the two trainees who had negative reactions in supervision were both men and shared the same male supervisor. Of course, there is no way to know whether gender contributed to the negative reactions.

\section{Experiences Other Than Supervision That Fostered Growth}

Trainees used a number of strategies to help them manage their anxieties. When they were face-to-face with clients in sessions, they used positive self-talk (talked silently to themselves and gave themselves reassurance, often derived from what they were learning about doing psychotherapy, e.g., "I felt challenged by the complexity of her problems but I reassured myself by remembering that it is not

Psychotherapy: Theory, Research, Practice, Training, Vol. 44, No. 4 (December 2007): pg. 434-449. DOI. This article is (C) American Psychological Association and permission has been granted for this version to appear in e-

Publications@Marquette. American Psychological Association does not grant permission for this article to be further copied/distributed or hosted elsewhere without the express permission from American Psychological Association. 
my 'job' to solve them."), focused on the helping skills as a way of dealing with anxiety, and redirected their focus toward the client. Between sessions, trainees prepared for the logistics of sessions (e.g., practiced the session introduction regarding confidentiality and informed consent, got to the session early to set up the tape recorder) to make sure that what they could control went smoothly. In addition, they wrote in their journals to process their reactions (e.g., "It's been very helpful to have ... this journal to look at that [being hard on self] again."). These activities helped some trainees prepare themselves for the sessions and process their feelings and reactions.

\section{Illustrative Example}

To bring the qualitative results to life, we present a case example based on the journals of one trainee, whom we will call "Dana." We chose this trainee because she seemed to be fairly representative of the entire cohort. To protect confidentiality, we omit demographic data (we use "she" generically because there were more women in the cohort).

The major attributes that permeated Dana's journals were perfectionism, self-criticalness, and deep self-reflection. She was anxious about doing the "right" thing, worried about lacking clinical self-efficacy, and had hindering self-awareness in sessions. Dana was particularly eloquent about her reactions to clients, talking about how she overidentified with some of the clients because they reminded her of a relative who had serious psychiatric problems. She was also quite open about her urges to fix clients, disclose to them, and soothe them. In addition, she struggled a lot learning to use the insight skills (particularly interpretations and immediacy) and action skils and integrating the skills.

Dana made marked progress during the semester. She improved substantially in using exploration skills (particularly silence and empathy) and action skills, and her anxiety decreased. She was especially active in finding ways to grow: Prior to sessions she practiced the skills, during sessions she relied on the helping skills to make her feel comfortable, and between sessions she used the journal to help her sort through her feelings. She had a very positive relationship with her supervisor, whom she thought helped by

Psychotherapy: Theory, Research, Practice, Training, Vol. 44, No. 4 (December 2007): pg. 434-449. DOI. This article is (C) American Psychological Association and permission has been granted for this version to appear in e-

Publications@Marquette. American Psychological Association does not grant permission for this article to be further copied/distributed or hosted elsewhere without the express permission from American Psychological Association. 
providing instruction and support and facilitated exploration of her personal feelings and anxieties. We had a very positive reaction to reading Dana's journals: We were impressed that she explored her feelings deeply and was willing to learn new things.

\section{Discussion}

This investigation of the experiences of five trainees in a prepracticum course in their counseling psychology doctoral program provides some insight into the experience of becoming a therapist. The major challenges were self-criticism, managing reactions to clients, learning and using the helping skills, and session management; the gains were primarily in the areas of learning and using the helping skills, becoming less self-critical, and being able to connect with clients. Individual supervision helped trainees learn about doing psychotherapy, although occasionally problems in supervisory relationships needed to be repaired. In addition, trainees used both insession activities (e.g., positive self-talk) and activities outside of sessions (e.g., journaling) to manage anxieties. In this section, we discuss the findings as they relate to five broad areas: feelings about self in role of therapist, awareness of reactions to clients, learning and using helping skills, reactions to supervision, and experiences that fostered growth.

\section{Feelings About Self in Role of Therapist}

In the space of one semester, trainees became much less anxious, gained confidence in their therapeutic abilities, and became more comfortable in the therapist role. In addition, they became aware of perfectionistic strivings and need to have control over clients and the psychotherapy situation. These results are important because, as trainers of new therapists, we often consider our most important goal to be teaching students the tasks of psychotherapy, the helping skills, or the theoretical approaches to psychotherapy. Less often do we deliberately seek to help students manage their inevitable internal reactions to the process of learning to be psychotherapists, yet it is in this very arena that much of the significant growth occurred. This process is analogous to playing the violin: The musician needs to have the technical skills to play the instrument, but the violin must be in

Psychotherapy: Theory, Research, Practice, Training, Vol. 44, No. 4 (December 2007): pg. 434-449. DOI. This article is (C) American Psychological Association and permission has been granted for this version to appear in e- 
tune for the music to sound pleasing. Likewise, psychotherapists must not only have the technical skills to conduct sessions (i.e., the helping skills), but they must also be "in tune" (e.g., relatively free of hindering self-awareness, fully present, with facilitative selfawareness) so that they can help clients. We, as trainers of psychotherapists, must likewise attend not only to whether or not the violin player knows how to play the notes but also to whether or not the instrument itself is in tune.

Our findings here parallel previous literature on the development of novice psychotherapists. Specifically, previous studies have found evidence for the salience of anxiety, self-awareness, selfefficacy as a psychotherapist, self-criticalness of performance in sessions, and concerns about taking on the role of psychotherapist in the inner experiences of novice psychotherapists (Bischoff, Barton, Thober, \& Hawley, 2002; Howard et al., 2006; Lee et al., 2001; Williams et al., 1997). Similarly, extensive research has found that novice psychotherapists gain in counseling self-efficacy over time (e.g., R. L. Lent et al., 2006; R. W. Lent, Hill, \& Hoffman, 2003). Taken in conjunction with the previous literature, our results emphasize the importance of focusing on self-awareness in training so that trainees can more fully use themselves in the therapeutic process (see also Williams \& Fauth, 2005).

\section{Awareness of Reactions to Clients}

These trainees also struggled with and learned to manage intense reactions to clients. One such reaction was feeling upset when clients did not meet their expectations. Trainees hoped that clients would be open and eager to explore their problems; they wanted the clients to be not so healthy that they had nothing to talk about but also not so disturbed that they could not be readily helped. Perhaps these expectations reflected trainees' need for control or predictability and their wish to be assigned "easy" or "safe" clients, for it is unnerving not to be able to anticipate or plan what to do in a session. With little prior clinical experience to guide them, the trainees found that the need for flexibility with clients who did not match their expectations was quite challenging. Similarly, Howard et al. (2006) highlighted the struggle of novice trainees in learning to tolerate

Psychotherapy: Theory, Research, Practice, Training, Vol. 44, No. 4 (December 2007): pg. 434-449. DOI. This article is (C) American Psychological Association and permission has been granted for this version to appear in e- 
ambiguity. In addition, Jennings and Skovholt (2004) found that an ability to accept and embrace ambiguity is typical of master therapists, but they suggested that it takes time and clinical experience to develop such tolerance.

Moreover, trainees often worried about being able to help clients who they felt were either too similar to or too different from them, suggesting that these trainees struggled with how to empathize with clients. Trainees also reported feeling pulled to make clients feel better, perhaps as they had done with friends. Such concerns reflect developmentally appropriate challenges for beginning psychotherapists, who must learn what it means to be therapeutic and what boundaries they must maintain to facilitate that process. These results are similar to those found by Williams et al. (1997), confirming the importance of focusing on such reactions for beginning psychotherapists. Furthermore, awareness of reactions to clients seems to be a prerequisite for learning to understand and use such reactions therapeutically (Gelso \& Hayes, 2007).

\section{Learning and Using Helping Skills}

These novice trainees wrote frequently about learning and using helping skills (e.g., exploration, insight, and action skills) in sessions with clients. Clearly, this aspect of training was central to these trainees, perhaps because it was so much a focus of the class. In addition, it seemed that trainee self-confidence was bolstered by having something on which to focus. For example, trainees mentioned that when they felt anxious, they remembered that they could use reflections of feelings to help clients explore. If trainees gradually trust that they will be able to offer appropriate interventions, then they will likely feel more comfortable working with clients, even at this very early stage of development.

Trainees wrote most about the exploration and insight skills and only minimally about the action skills and integration of skills. It may be that trainees wrote little about action skills because these were not presented until the end of the semester and thus there was little time to write about them. We also speculate that, in one semester, trainees began to feel somewhat competent using the exploration skills and had a glimmer of how to use the insight skills but had difficulty moving on

Psychotherapy: Theory, Research, Practice, Training, Vol. 44, No. 4 (December 2007): pg. 434-449. DOI. This article is (C) American Psychological Association and permission has been granted for this version to appear in e-

Publications@Marquette. American Psychological Association does not grant permission for this article to be further copied/distributed or hosted elsewhere without the express permission from American Psychological Association. 
to action skills and integrating all of the skills. Our experience is that trainees can learn how to phrase the skills and use them in roleplaying situations within a relatively short time but that it takes much longer to master the skills, incorporate them deeply into one's repertoire, and use them effectively with clients. Similarly, students have told us that it takes a few years of practicing the helping skills before they master them enough that the skills become automatic and recede into the background (as has been suggested in the cognitive literature on the development of expertise, e.g., Cummings, Slemon, \& Hallberg, 1993; Sakai \& Nasserbakht, 1997).

\section{Reactions to Supervision}

Of particular importance to these trainees was individual supervision. They mentioned a number of specific helpful things that supervisors did (e.g., instruction, support, facilitation of exploration, and challenge). These results support previous findings about the importance of individual supervision for beginning graduate trainees (Heppner \& Roehlke, 1984; Rabinowitz et al., 1986) and suggest that helping skills training and supervision may operate synergistically to help students become better psychotherapists.

Although all trainees reported positive feelings about their supervisors, it is important to note that some also described at least temporary differences of opinion or negative experiences. Clearly, these results show that supervision is not uniformly positive. The results also show, however, that initially poor supervisory relationships can be repaired if supervisors are aware of the problems and work with their supervisees to negotiate the relationship and address the concerns. It probably helped that the student supervisors were themselves being supervised as part of a supervision class and thus were learning how to process ruptures in supervision.

\section{Experiences That Fostered Growth}

Trainees wrote about a range of experiences that helped them grow during the semester, thereby suggesting that the trainees were active agents in their development, learning and using not only the helping skills but also other techniques for managing their anxieties 
(e.g., positive self-talk, focusing on the client, mindfulness). Results in this area are similar to those found in Williams et al. (1997), confirming the importance of teaching management strategies to trainees as part of the training experience. The discovery that individual trainees found different activities to be helpful indicates that trainers and supervisors need to work with trainees to determine which activities might be useful for them individually.

\section{Comparison With Previous Studies}

A comparison of the results of the current investigation with those of previous empirical studies suggests that the findings are most similar to Williams et al. (1997), which is perhaps not surprising given that the studies were completed using students in the same program with the same professor (from different cohorts). Both studies found that trainees were concerned about their therapeutic skills, performance, ability to connect with clients, anxiety, self-efficacy, role as psychotherapist, similarities and differences from clients, problematic reactions to clients, and management strategies for coping with problematic reactions. The present study, however, provided a richer description of the experiences of novice psychotherapists than was possible in the Williams et al. study, which involved a qualitative analysis of data collected from an open-ended questionnaire administered immediately after sessions with volunteer clients. Thus, for example, we learned more about trainees' anxieties and the variety of their problematic reactions to clients. Furthermore, the trainees in the present study were asked to reflect on any part of the process of becoming a therapist, whereas trainees in the Williams study were limited to reflecting only on their experiences in conducting sessions. Perhaps because of this broader focus, the present study identified one category related to both challenges and gains not found in the Williams study (i.e., session management) and several helpful activities not identified by Williams et al. (i.e., supervision, preparation for logistics, journaling, positive self-talk, focus on helping skills, and practicing the skills).

A comparison of the results of all five studies that have focused on the experiences of novice therapists (Bischoff et al., 2002; Howard et al., 2006; Lee et al., 2001; Williams et al., 1997; present study) 
reveals some interesting trends, as well. All five studies found evidence for the importance of self-awareness and self-efficacy as a therapist. Four studies (Howard et al., 2006; Lee et al., 2001; Williams et al., 1997; present study) yielded findings related to feelings of similarity and differences in relation to clients. Three studies (Lee et al., 2001; Williams et al., 1997; present study) reported results related to trainee self-criticism of performance in sessions, concerns about taking on the therapist role, difficulties related to clients not meeting trainees' expectations, the helpful nature of supervision, and self-reflection. Hence, there was some overlap in findings across the five studies, indicating some common themes across samples and methodologies. The integration of these results, then, suggests that novice trainees are concerned both about the technical skills involved in conducting sessions with clients and about being aware of and managing their internal reactions. On the one hand, trainees attend to real-world, practical, functional, and overt challenges of learning to be psychotherapists and what to do to be competent. On the other hand, they also wrestle with their own more covert processes related to what it feels like to be a psychotherapist. Both external and internal aspects of development, then, should be addressed in training (see later discussion).

\section{Comparison to Description of Novice Trainees in Developmental Theories}

As has been described in developmental theories (see review in Skovholt \& Ronnestad, 1992), these novice trainees indeed talked about anxieties, self-criticism, and doubts and also about difficulties in taking on the professional role of being a psychotherapist. Contrary to those theories, however, these trainees did not talk about imitating their professors and supervisors. Of course, it should be noted that this professor did not emphasize modeling but rather emphasized roleplaying and practicing with clients as central learning techniques. Similarly, Howard et al. (2006) observed that their novice trainees exhibited more insight, conceptualization ability, and ability to consider the implications of their reactions to clients than would be expected from reading the developmental theories. The cumulative results of these investigations thus suggest that we may need to modify

Psychotherapy: Theory, Research, Practice, Training, Vol. 44, No. 4 (December 2007): pg. 434-449. DOI. This article is (C) American Psychological Association and permission has been granted for this version to appear in e- 
NOT THE PUBLISHED VERSION; this is the author's final, peer-reviewed manuscript. The published version may be accessed by following the link in the citation at the bottom of the page.

developmental theories to reflect that some novice trainees are quite agentic, flexible, and insightful.

\section{Comparison of Results to Topics Covered in Class}

It is not surprising that the topics raised in the journals were also ones that were raised in the classroom. Trainees talked extensively in class about learning and using the skills, about their inner reactions to themselves and to clients, and about hot buttons. The journals did seem helpful for individual trainees in allowing them to expand on these topics more extensively. Furthermore, the trainees' intensive emphasis in their journals on self-criticism and internal reactions in comparison to their concern about learning and implementing the skills was a revelation, suggesting that we may need to alter the way training is conducted (see following discussion). In addition, the reactions of this cohort were relatively similar to those of novice trainees in previous cohorts (Hill et al., 1981; Williams et al., 1997), suggesting that these data are representative of students in this program.

\section{Limitations}

As with any study with a small sample size, the results may not generalize to other students in other classes with other professors. We remind readers that the five trainees were bright, relatively young (with one exception), European American (with one exception) and were clinically inexperienced, although there was diversity in terms of gender (three women, two men).

Another limitation involves collecting sensitive data within the context of a graduate class. Students seemed to feel comfortable with the professor, disclosed readily and deeply in their journals about sensitive topics (although we have no way of knowing what they did not disclose), and did not report any reluctance to participate. The journals were part of the class requirements (as is not uncommon in graduate classes) and so required no extra time on the part of students. In fact, some of the students preferred the journaling requirement to requirements in previous classes (e.g., a final exam). Another concern is that not all students like to do journaling; in fact,

Psychotherapy: Theory, Research, Practice, Training, Vol. 44, No. 4 (December 2007): pg. 434-449. DOI. This article is (C) American Psychological Association and permission has been granted for this version to appear in e-

Publications@Marquette. American Psychological Association does not grant permission for this article to be further copied/distributed or hosted elsewhere without the express permission from American Psychological Association. 
although four of the students really liked journaling, one student did not like it and found it difficult to engage in the activity. Hence, the results may generalize only to training that involves journaling and the use of the Hill (2004a) model of teaching helping skills within the context of a prepracticum experience at the graduate level.

In addition, the data were co-constructed between the trainees, professor, and GRA. The professor chose what was covered in the class, was privy to all that went on overtly in the class, read and responded to the journals, and so undoubtedly influenced what the students learned during the semester and how they experienced their learning. In addition, the students influenced the professor and each other because they brought their own personalities and skills to the course. Furthermore, the clients influenced the trainees' experiences of sessions. Had trainees worked with "real" therapy clients (e.g., more severely disturbed clients), they would probably have had different experiences (e.g., might not have felt that clients were too psychologically sophisticated to need their help). Finally, the supervisors and the match between the trainees and supervisors undoubtedly influenced trainees' experiences in supervision (e.g., the female trainees paired with female supervisors were quite happy about their matches, whereas the male trainees paired with a male supervisor had more contention).

\section{Implications for Training}

The findings of this study provide several implications for training. First, continued attention on helping skills training seems justified. Having a foundation of skills to use in sessions provides a focus for trainees and may give them greater confidence with clients (e.g., they can tell themselves to reflect feelings and not give advice). In addition, the finding that at the end of the semester trainees were most comfortable using the exploration skills and relatively comfortable using the insight skills suggests that a semester-long training experience is a good beginning vehicle for teaching these skills. We speculate, however, that more than one semester of training is needed to help students feel comfortable with the action skills and with integrating all of the skills. 
NOT THE PUBLISHED VERSION; this is the author's final, peer-reviewed manuscript. The published version may be accessed by following the link in the citation at the bottom of the page.

Second, individual supervision seemed crucial to trainee development. Intensive supervision provides the opportunity to tailor training to meet the needs of individual learners, likely allows students to better implement the helping skills that they learned in group training, and, perhaps most important, provides a forum for discussing thoughts and feelings about the inherently challenging process of becoming a psychotherapist.

A third component of training involves helping trainees manage internal processes, such as anxiety, concerns about self-efficacy, and hot buttons. In their journals, trainees provided ideas for possible interventions in their descriptions of activities that helped them cope with their anxieties. In addition to supervision, for example, they prepared for the logistics of sessions and used journaling to help them absorb and process their new experiences. During sessions, they used positive self-talk and focused on the helping skills and also on the client. Some combination of these activities could be included in training for novice trainees. In addition, we suggest that trainers use experiential exercises to help trainees become aware of hot buttons and encourage open discussion of unsettling feelings to normalize such reactions.

A fourth component for training is to help trainees process their reactions to clients. If trainees are to use themselves effectively as psychotherapists, then they probably need to be aware of their positive and negative reactions to clients, their fears and urges, and what clients pull from them. After learning the basic helping skills, trainees could view videotapes of clients expressing anger, seduction, or passivity, for example, and practice addressing such challenging situations more appropriately and with less anxiety (see one such training effort in Hess, Knox, \& Hill, 2006).

\section{Implications for Future Research}

It would be interesting to use this qualitative method of examining journals to investigate the experiences of different subgroups of novice trainees. For example, how might the experiences differ for trainees who have prior counseling experience, see more difficult clients initially, do not participate in helping skills training, or do not receive individual supervision? Likewise, researchers could

Psychotherapy: Theory, Research, Practice, Training, Vol. 44, No. 4 (December 2007): pg. 434-449. DOI. This article is (C) American Psychological Association and permission has been granted for this version to appear in e-

Publications@Marquette. American Psychological Association does not grant permission for this article to be further copied/distributed or hosted elsewhere without the express permission from American Psychological Association. 
examine trainees' experiences over the course of graduate school as they progress in their training. Another area for research would be to investigate the experiences of trainees with different types of training (e.g., experiential vs. didactic).

In addition, a comprehensive battery of paper-and-pencil measures could be developed based on these results. Measures could include competence with helping skills from the client perspective, anxiety, self-efficacy, self-awareness, self-reflection, professionalism, case conceptualization, comfort in the role of psychotherapist, and openness to supervision. Such an assessment battery would enable us to comprehensively investigate the effects of helping skills training.

\section{Notes}

- Clara E. Hill and Catherine Sullivan, Department of Psychology, University of Maryland; Sarah Knox, Department of Counseling and Educational Psychology, Marquette University; Lewis Z. Schlosser, Department of Professional Psychology and Family Therapy, Seton Hall University.

- This study was presented at the Mid-Atlantic Society for Psychotherapy Research, St. Mary's College, St. Mary's, Maryland, October 15, 2005.

- We are grateful to the five trainees who participated in this study and to Jessica Stahl for reading a draft of the manuscript.

- Correspondence regarding this article should be addressed to Clara E. Hill, PhD, Department of Psychology, University of Maryland, College Park, MD 20742. E-mail: hill@psyc.umd.edu

\section{References}

Atkinson, D. R. (2004). Counseling American minorities (6th ed.). New York: McGraw-Hill.

Bischoff, R. J., Barton, M., Thober, J., \& Hawley, R. (2002). Events and experiences impacting the development of clinical self confidence: $A$ study of the first year of client contact. Journal of Marital and Family Therapy, 28, 371-382.

Burnett, P., \& Meacham, D. (2002). Learning journals as a counseling strategy. Journal of Counseling and Development, 80, 410-415.

Psychotherapy: Theory, Research, Practice, Training, Vol. 44, No. 4 (December 2007): pg. 434-449. DOI. This article is (C) American Psychological Association and permission has been granted for this version to appear in ePublications@Marquette. American Psychological Association does not grant permission for this article to be further copied/distributed or hosted elsewhere without the express permission from American Psychological Association. 
NOT THE PUBLISHED VERSION; this is the author's final, peer-reviewed manuscript. The published version may be accessed by following the link in the citation at the bottom of the page.

Cummings, A. L., Slemon, A. G., \& Hallberg, E. T. (1993). Session evaluation and recall of important events as a function of counselor experience. Journal of Counseling Psychology, 42, 156-165.

Elliott, R., Watson, J. C., Goldman, R. N., \& Greenberg, L. S. (2004). Learning emotion-focused therapy: The process-experiential approach to change. Washington, DC: American Psychological Association.

Fleming, J. (1953). The role of supervision in psychiatric training. Bulletin of the Menninger Clinic, 17, 157-159.

Furr, S. R., \& Carroll, J. J. (2003). Critical incidents in student counselor development. Journal of Counseling \& Development, 81, 483-489.

Gelso, C. J., \& Hayes, J. A. (2007). Countertransference and the therapist's inner experience. Mahwah, $\mathrm{NJ}$ : Erlbaum.

Grater, H. A. (1985). Stages in psychotherapy supervision: From therapy skills to skilled therapist. Professional Psychology: Research and Practice, 16, 605-610.

Heppner, P. P., \& Roehlke, H. J. (1984). Differences among supervisees at different levels of training: Implications for a developmental model of supervision, Journal of Counseling Psychology, 31, 76-90.

Hess, A. K. (1987). Psychotherapy supervision: Stages of supervisee and supervisor development. Professional Psychology: Theory, Research, and Practice, 18, 251-259.

Hess, S., Knox, S., \& Hill, C. E. (2006). Teaching graduate student trainees how to manage client anger: A comparison of three types of training. Psychotherapy Research, 16, 282-292.

Hill, C. E. (2004a). Helping skills: Facilitating exploration, insight, and action (2nd ed.). Washington, DC: American Psychological Association.

Hill, C. E. (Ed.). (2004b). Dream work in therapy: Facilitating exploration, insight, and action. Washington, DC: American Psychological Association.

Hill, C. E., Charles, D., \& Reed, K. G. (1981). A longitudinal analysis of counseling skills during doctoral training in counseling psychology. Journal of Counseling Psychology, 28, 428-436.

Psychotherapy: Theory, Research, Practice, Training, Vol. 44, No. 4 (December 2007): pg. 434-449. DOI. This article is (C) American Psychological Association and permission has been granted for this version to appear in e-

Publications@Marquette. American Psychological Association does not grant permission for this article to be further copied/distributed or hosted elsewhere without the express permission from American Psychological Association. 
NOT THE PUBLISHED VERSION; this is the author's final, peer-reviewed manuscript. The published version may be accessed by following the link in the citation at the bottom of the page.

Hill, C. E., Knox, S., Thompson, B. J., Williams, E. N., Hess, S., \& Ladany, N. (2005). Consensual qualitative research: An update. Journal of Counseling Psychology, 52, 196-205.

Hill, C. E., Thompson, B. J., \& Williams, E. N. (1997). A guide to conducting consensual qualitative research. The Counseling Psychologist, 25, 517572.

Hogan, R. A. (1964). Issues and approaches in supervision. Psychotherapy: Theory, Research, and Practice, 1, 139-141.

Howard, E. E., Inman, A. G., \& Altman, A. N. (2006). Critical incidents among novice counselor trainees. Counselor Education and Supervision, 46, 88-102.

Howatt, W. A. (1999). Journaling to self-evaluation: A tool for adult learners. International Journal of Reality Therapy, 18, 32-34.

Jennings, L., \& Skovholt, T. (2004). The cognitive, emotional, and relational characteristics of master therapists. In T.Skovholt \& L.Jennings (Eds.), Master therapists: Exploring expertise in therapy and counseling ( $\mathrm{pp}$. 31-52). Boston: Pearson Education.

Kidd, S. A., \& Kral, M. J. (2005). Practicing participatory action research. Journal of Counseling Psychology, 52, 187-195.

Lee, R. E., Eppler, C., Kendal, N., \& Latty, C. (2001). Critical incidents in the professional lives of first year MFT students. Contemporary Family Therapy, 23, 51-61.

Lent, R. L., Hoffman, M. A., Hill, C. E., Treistman, D., Mount, M., \& Singley, D. (2006). Client-specific counselor self-efficacy in novice counselors: Relation to perceptions of session quality. Journal of Counseling Psychology, 53, 453-463.

Lent, R. W., Hill, C. E., \& Hoffman, M. A. (2003). Development and validation of the Counselor Activity Self-Efficacy Scales. Journal of Counseling Psychology, 50, 97-108.

Linehan, M. M. (1993). Cognitive-behavioral treatment of borderline personality disorder. New York: Guilford Press.

Psychotherapy: Theory, Research, Practice, Training, Vol. 44, No. 4 (December 2007): pg. 434-449. DOI. This article is (C) American Psychological Association and permission has been granted for this version to appear in ePublications@Marquette. American Psychological Association does not grant permission for this article to be further copied/distributed or hosted elsewhere without the express permission from American Psychological Association. 
NOT THE PUBLISHED VERSION; this is the author's final, peer-reviewed manuscript. The published version may be accessed by following the link in the citation at the bottom of the page.

Loganbill, C., Hardy, E., \& Delworth, U. (1982). Supervision: A conceptual model. The Counseling Psychologist, 10, 3-42.

McWilliams, N. (2004). Psychoanalytic psychotherapy: A practitioner's guide. New York: Guilford Press.

Miller, W. R., \& Rollnick, S. (2002). Motivational interviewing: Preparing people for change. New York: Guilford Press.

Mishler, E. G. (1990). Validation in inquiry-guided research: The role of explanation in narrative studies. Harvard Education Review, 60, 415440.

Moustakas, C. (1990). Heuristic research design, methodology, and application. Newbury Park, CA: Sage.

Naviaux, L. D. (1980). The intensive journal process: A method for integrating life's experiences. Journal of Mental Imagery, 4, 83-86.

Progoff, I. (1977). At a journal workshop: The basic text and guide for using the intensive journal. Oxford, England: Dialogue House Library.

Rabinowitz, F. E., Heppner, P. P., \& Roehlke, H. J. (1986). Descriptive study of process and outcome variables of supervision over time, Journal of Counseling Psychology, 33, 292-300.

Rhodes, R., Hill, C. E., Thompson, B. J., \& Elliott, R. (1994). Client retrospective recall of resolved and unresolved misunderstanding events. Journal of Counseling Psychology, 41, 473-483.

Safran, J., \& Muran, C. (2003). Negotiating the therapeutic alliance. New York: Guilford Press.

Sakai, P. S., \& Nasserbakht, A. (1997). Counselor development and cognitive science models of expertise: Possible convergences and divergences. Educational Psychology Review, 9, 353-359.

Skovholt, T. M., \& Ronnestad, M. H. (1992). The evolving professional self: Stages and themes in therapist and counselor development. New York: Wiley.

Tsang, W. K. (2003). Journaling from internship to practice teaching. Reflective Practice, 4, 221-240.

Psychotherapy: Theory, Research, Practice, Training, Vol. 44, No. 4 (December 2007): pg. 434-449. DOI. This article is (C) American Psychological Association and permission has been granted for this version to appear in ePublications@Marquette. American Psychological Association does not grant permission for this article to be further copied/distributed or hosted elsewhere without the express permission from American Psychological Association. 
NOT THE PUBLISHED VERSION; this is the author's final, peer-reviewed manuscript. The published version may be accessed by following the link in the citation at the bottom of the page.

Wagoner, D., \& Wijekumar, K. (2004). Improving self-awareness of nutrition and lifestyle practices through on-line journaling. Journal of Nutrition Education and Behavior, 36, 211-212.

Williams, E. N., \& Fauth, J. (2005). A psychotherapy process study of therapist in session self-awareness. Psychotherapy Research, 15, 374381.

Williams, E. N., Judge, A., Hill, C. E., \& Hoffman, M. A. (1997). Experiences of novice therapists in prepracticum: Trainees', clients' and supervisors' perceptions of therapists' personal reactions and management strategies, Journal of Counseling Psychology, 44, 390-399.

Psychotherapy: Theory, Research, Practice, Training, Vol. 44, No. 4 (December 2007): pg. 434-449. DOI. This article is (C) American Psychological Association and permission has been granted for this version to appear in ePublications@Marquette. American Psychological Association does not grant permission for this article to be further copied/distributed or hosted elsewhere without the express permission from American Psychological Association. 
NOT THE PUBLISHED VERSION; this is the author's final, peer-reviewed manuscript. The published version may be accessed by following the link in the citation at the bottom of the page.

TABLE 1. Frequency of Domains and Categories for Trainees' Experiences in Becoming Psychotherapists

\begin{tabular}{|c|c|}
\hline Domains/categories & Frequency \\
\hline 1. Challenges & $5 \mathrm{~T} ; 0 \mathrm{~V}$ \\
\hline A. Self-criticism & $3 \mathrm{~T} ; 2 \mathrm{~V}$ \\
\hline I. Anxiety & $2 \mathrm{~T} ; 3 \mathrm{~V}$ \\
\hline a. Not knowing what to do & $2 \mathrm{~T} ; 3 \mathrm{~V}$ \\
\hline b. Doing the "right" thing & $0 \mathrm{~T} ; 5 \mathrm{~V}$ \\
\hline 2. Other self-eriticisms & $2 \mathrm{~T} ; 3 \mathrm{~V}$ \\
\hline B. Reactions to clients & $3 \mathrm{~T} ; 2 \mathrm{~V}$ \\
\hline I. Identification issues & IT: $4 \mathrm{~V}$ \\
\hline a. Underidentification with clients & $0 \mathrm{~T}: 5 \mathrm{~V}$ \\
\hline b. Overidentification with clients & $0 \mathrm{~T}: 3 \mathrm{~V}$ \\
\hline 2. Client did not fit "ideal" & $0 \mathrm{~T} ; 5 \mathrm{~V}$ \\
\hline 3. Traince pulled to step out of therapist role & OT: $3 \mathrm{~V}$ \\
\hline C. Learning and using helping skills & IT: $4 \mathrm{~V}$ \\
\hline 1. Exploration skills & $0 \mathrm{~T}: 5 \mathrm{~V}$ \\
\hline a. Exploration skills generally & $0 \mathrm{~T}: 5 \mathrm{~V}$ \\
\hline b. Open question & $0 \mathrm{~T}: 3 \mathrm{~V}$ \\
\hline 2. Insight skills & $0 \mathrm{~T}: 5 \mathrm{~V}$ \\
\hline a. Insight skills generally & $0 \mathrm{~T}: 5 \mathrm{~V}$ \\
\hline b. Interpretation & $0 \mathrm{~T}: 3 \mathrm{~V}$ \\
\hline D. Session managenent & $0 \mathrm{~T}: 5 \mathrm{~V}$ \\
\hline II. Gains & $4 \mathrm{~T} ; \mathrm{IV}$ \\
\hline A. Using the helping skills & $4 \mathrm{~T}: \mathrm{IV}$ \\
\hline 1. Exploration skills & IT: $4 \mathrm{~V}$ \\
\hline a. Reflection of feelings & $0 \mathrm{~T}: 3 \mathrm{~V}$ \\
\hline b. Restatement & $0 \mathrm{~T}: 3 \mathrm{~V}$ \\
\hline c. Open question & $0 \mathrm{~T}: 3 \mathrm{~V}$ \\
\hline d. Silence & or: $3 \mathrm{~V}$ \\
\hline e. Exploration skills generally & $0 \mathrm{r} ; 3 \mathrm{~V}$ \\
\hline 2. Insight skills & oT; $5 \mathrm{~V}$ \\
\hline a. Challenge & $0 \mathrm{~T} ; 4 \mathrm{~V}$ \\
\hline b. Immediacy & $0 \mathrm{~T} ; 3 \mathrm{~V}$ \\
\hline c. Insight skills generally & $0 \mathrm{~T}: 3 \mathrm{~V}$ \\
\hline B. Feeling better about self as therapist & $0 \mathrm{~T} ; 5 \mathrm{~V}$ \\
\hline 1. Less anxious & $0 \mathrm{~T}: 5 \mathrm{~V}$ \\
\hline 2. Increased self-efficacy & oT: $4 \mathrm{~V}$ \\
\hline 3. Role of therapist fits better & $0 \mathrm{~T} ; 3 \mathrm{~V}$ \\
\hline C. Able to connect with client & $0 \mathrm{~T}: 3 \mathrm{~V}$ \\
\hline III. Supervision & $3 \mathrm{~T}: 2 \mathrm{~V}$ \\
\hline A. Trainee used supervision & $0 \mathrm{~T}: 4 \mathrm{~V}$ \\
\hline B. Helpful supervisor activities & $2 \mathrm{~T}: 3 \mathrm{~V}$ \\
\hline 1. Supervisor provided instruction & $0 \mathrm{~T}: 5 \mathrm{~V}$ \\
\hline 2. Supervisor provided support & $0 \mathrm{~T} ; 4 \mathrm{~V}$ \\
\hline 3. Supervisor facilitated exploration & $0 \mathrm{~T} ; 4 \mathrm{~V}$ \\
\hline 4. Supervisor challenged or gave feedback & $0 \mathrm{~T}: 4 \mathrm{~V}$ \\
\hline C. Global positive feelings about supervision & $0 \mathrm{~T}: 5 \mathrm{~V}$ \\
\hline D. Neutral of negative feelings about supervision & $0 \mathrm{~T} ; 3 \mathrm{~V}$ \\
\hline \multicolumn{2}{|l|}{ IV. Experiences that fostered awareness } \\
\hline A. Activities trainee used during sessions & or; $4 \mathrm{~V}$ \\
\hline B. Activities trainee used outside sessions & $0 \mathrm{~T} ; 4 \mathrm{~V}$ \\
\hline
\end{tabular}

Note, $\quad N=5$. Each trainee had 16 possible journal entries for the first three domains (although note that they learned exploration skills at the beginning of the semester, insight skills in the middle, and action skills at the end and so would have less impetus to write about skills taught later in the semester), and 12 possible entries for the supervision domain. $T=$ typical indicates that the category occurred in more than half of the entries for a trainee; $\mathrm{V}=$ variant indicates that the category occurred in more than two but fewer than half of the entries for a trainee. Categories were only placed into the table if they were at least variant or typical for at least three trainees.

Psychotherapy: Theory, Research, Practice, Training, Vol. 44, No. 4 (December 2007): pg. 434-449. DOI. This article is (C) American Psychological Association and permission has been granted for this version to appear in ePublications@Marquette. American Psychological Association does not grant permission for this article to be further copied/distributed or hosted elsewhere without the express permission from American Psychological Association. 
NOT THE PUBLISHED VERSION; this is the author's final, peer-reviewed manuscript. The published version may be accessed by following the link in the citation at the bottom of the page.

Psychotherapy: Theory, Research, Practice, Training, Vol. 44, No. 4 (December 2007): pg. 434-449. DOI. This article is (C) American Psychological Association and permission has been granted for this version to appear in e-

Publications@Marquette. American Psychological Association does not grant permission for this article to be further copied/distributed or hosted elsewhere without the express permission from American Psychological Association. 